\title{
SOME SUGGESTIONS CONCERNING THE INTERNATIONAL TRADE MARK SITUATION
}

\author{
EDWARD S. ROGERS
}

Try to picture an angry and bewildered client who bursts into his counsel's office with this tale of woe. He is in the wholesale clothing business. He had, a few months back, an order from a merchant in a South American republic. He was glad to get it. It implied appreciation of his goods in distant places. His customer's credit, upon investigation, was found to be excellent. The goods were shipped, in due course arrived at their destination and then the trouble began.

The customer, before posting his order, had called at his National Trade Mark Registry Bureau and, finding that the manufacturer of the goods he was about to buy had not registered the trade mark under which they were sold, registered it himself in his own name. He then sent his order, after which he proceeded to the custom house, stating that a shipment might be expected shortly which he had reason to believe would bear his registered trade mark. He, therefore, desired to file a copy of his certificate of registration, so if his suspicions should turn out to be well founded, the spurious goods could be seized and delivered to him as contraband. And this, in due time, is exactly what happened.

This narrative was related with interruptions to relieve pentup emotion and to express picturesque and definite views of the trade morals of South Americans and foreigners generally. But nothing could be done. The South American merchant had proceeded in strict accordance with the laws of his own country. The result was that he got his shipment for nothing except what it cost to effect the registration; also he got a trade mark, made valuable by another's expenditure. The American manufacturer got what was left. It consisted almost entirely of experience.

Reverse the situation; a citizen of the same South American republic, let us say, has a trade mark which he uses in his own country and elsewhere in South America. For some reason his goods are not sold in the United States. Finally a time comes when he thinks conditions are favorable to introduce them here. He makes a shipment and is becoming established under the same trade mark he is using on his goods generally. He has applied for, and obtained without opposition, registration of his trade mark under our National Trade Mirk Act. He feels secure in his rights and begins to expand, when suddenly his 
agent in New York is served with a writ issued at the suit of an American citizen who asserts that the mark belongs to him because of his use of it in this country prior to the time the South American's goods were sold here.

An investigation discloses that the American had seen goods bearing the mark on a trip to South America. Being attracted by it, he appropriated and used it as his own and claimed common law rights in it on account of priority of use in the United States, in all of which under our law he was perfectly correct, and his rights were sustained by our courts in the suit he had brought against the importer of the South American's goods.' And once the common law theory of trade mark protection is understood, this result must follow as a matter of principle. A trade mark at common law is protected because, by association with certain goods it is accepted by the public as a guarantee of definite commercial origin, and hence the use or deceptive imitation of the mark by another misrepresents this commercial origin and deceives purchasers into buying the goods of the infringer as those of the producer, whose reputation the mark symbolizes. But if there is no use of the mark upon goods in the market, there is no identification by means of it, and hence it cannot indicate origin with anybody, and there can be no misrepresentation by its appropriation or imitation and, therefore, no deception of purchasers. As Mr. Justice Strong has said: ${ }^{2}$

“. . . in all cases where rights to the exclusive use of a trade-mark are invaded, it is invariably held that the essence of the wrong consists in the sale of the goods of one manufacturer or vendor as those of another; and that it is only when this false representation is directly or indirectly made that the party who appeals to a court of equity can have relief. This is the doctrine of all the authorities. Hence the trade-mark must either by itself, or by association, point distinctively to the origin or ownership of the article to which it is applied. The reason of this is that unless it does, neither can he who first adopted it be injured by any appropriation or imitation of it by others, nor can the public be deceived."

And as the only use our courts consider relevant is use in the United States, and as the American citizen first used the mark here and the merchandise with which it became associated here was his, necessarily it follows that, according to common law principles, the trade mark was his. But imagine, if you can, the frame of mind of the South American after his experience with

1 Richter v. Anchor Remedy Co., 52 Fed. 455 (C. C. W. D. Pa. 1892); Richter v. Reynolds, 59 Fed. 577 (C. C. A. 3d, 1893); Kohler v. Beeshore, 59 Fed. 572 (C. C. A. 3d, 1893) ; Kathreiner v. Kneipp, 82 Fed. 321 (C. C. A. 7 th, 1897).

2 Canal Co. v. Clark, 13 Wall. 311, at 322 (U. S. 1871). 
the common law system of trade mark protection, and his probable opinion of it and of commercial molality in the United States.

In both cases diplomacy tried its hand at arranging things, but nothing came of it. The parties to the controversy were Iully convinced that all citizens of the country where the diffculty arose are poisonous rascals. MIultiply this situation a few times and serious international friction develops. Legally, no. body is a rascal. The trouble is that legal systems are not the same. Each country is a separate unit-a watertight compartment. ${ }^{3}$ Inside it, its own laws govern; outside it, they have no effect. And the laws of each differ basically.

As a preliminary to the discussion of the international situation, there must constantly be borne in mind the fundamental Jifference between the legal systems of Continental Europe and South America, and the systems in force in the United States and in English speaking countries generally where the common law prevails. On the continent of Europe and in countries where the jurisprudence is based upon Roman law, substantially all the law is written. A given controversy must find itself supported in a written code or there is no law applicable. The result is a radical difference in the way that legal problems are approached. The English and ourselves take up a legal question, to use Dean Pound's phrase, practically and professionally. That is, counsel and the court, in effect, sit around a table and among themselves work out the problem, getting what light they can Irom earlier adjudications of similar questions and the fundsmental equities. The Continental lawrer approaches the ques. tion academically, by the technique of applying written texts. The answer, he says, lies in such and such a section of the eode or there is not any answer. The result is that the Con inental law lends itself to subtlety and refinement. In short, to express difference by analogy, the common law and the Continental law differ just about as religion differs from theology. This basic difference must be borne in mind in order that the two different trade mark systems which are in existence-the common law theory and the statutory-may be understood.

3 Bourjois \& Co. v. Katzel, 260 U. S. 689, 43 Sup. Ct. 244 (1923); In re Berna Commercial Mrotors, Ltd. [1915] $1 \mathrm{Ch}$. 414; Baglin v. Cusenier Co, 221 U. S. 580, 31 Sup. Ct. 669 (1911) ; Rey v. Lccouturier [1008] $2 \mathrm{Ch}$ 715 , aff'd [1910] A. C. 262. In the United States the territorial subdi7ision of trade mark rights has extended so far as to recognize concurrent ownership of the same mark by different traders in different states. General Baking Co. v. Gorman, 3 Fed. (2d) 891 (C. C. A. 1st, 1925); United Drug Co. v. Rectanus Co., 248 U. S. 90, 39 Sup. Ct. 48 (1918); Hanove? Star MIilling Co. v. Allen \& Wheeler Co., 240 U. S. 403, 36 Sup. Ct. 257 (1916), particularly MIr. Justice Holmes' opinion at $424,426,36$ Sup. Ct. at 364, 365; Narragansett Dairy Co. v. Ammon \& Person, 262 Fed. 880, 881 (C. C. A. 1st, 1919). 
Under the common law, the right to a trade mark depends upon use. Trade marks at common law are symbols of good will. A trader uses a certain mark upon his goods. By this association the mark comes to be relied upon by the public as identifying that trader's goods. For another to use or imitate this mark is to misrepresent his goods as those of the original trader whose good will and reputation it represents, and this is a fraud which a court of equity will enjoin.

Under the Continental system, use is nothing, public association is nothing. Record a mark in a book in a public office and ipso facto it becomes the property of the person who first records it.

There are two theories of statutory trade mark protection resulting from the two legal systems. The one which has prevailed in this country is that the common law creates the right, and registration is only evidence of it. Trade mark statutes in the United States are, therefore, essentially practice acts. The other theory upon which the statutes of substantially all, if not all, Latin-American countries is based, is that registration creates the right. In these countries, unless and until a mark is registered, it is available for anybody's appropriation, and, conversely, when it is registered, it becomes incontestably the property of the registrant, for the title based on registration cannot be disputed. This theory of trade mark protection has the advantage of certainty and precision. There is no doubt of its efficiency to protect trade marks. It has, however, come in for a good deal of criticism. It is said that it lends itself to piracy and that it is generally unfair and unjust. But it is logical, if the premise on which it is founded be admitted, and that it protects trade marks is indisputable. That it sometimes protects the wrong person, according to our notions, is not a valid objection, because the right person could equally be protected if he took the pains to acquaint himself with the foreign law and availed himself of it.

No comprehensive national statute of this sort is possible in the United States on account of constitutional limitations on the power of Congress, the common law being the basis of trade mark right, and interstate commerce the limit of national authority over the subject.

Since in this country, use and public identification resulting from it, create the right, it follows that here statutory registration is merely confirmatory by affording a public record of claims of ownership based upon use. The federal trade mark statutes create nothing; they do not confer any title upon the registrant; they do not deprive anyone not registered of any title; they merely create a presumption of ownership and afford procedural 
and jurisdictional advantages-that is, the plaintiff whose marl is registered may resort to the federal courts for relief against infringement and, in proving his case, merely offers his certificate of registration in evidence, raising the presumptinn, unless rebutted, that the plaintiff is the owner at common law of the trade mark and that it is prime facic a good one. This is the logical result of the common law theory of trade morlis, just as the incontestable right created by registration is the logical result of the civil law theory, and it is this difference in legal concepts that creates the trouble in foreign countries for American trade mark owners. Little difficulty may be expected in Great Britain, in Canada, in Australia and New Zealand, and in British colonies generally, where the common law prevails for there the system approximates ours, but in the countries of Continental Europe, in South and Central America, American trade mark owners seem always to be in hot water due, apparently, to the failure to appreciate the difference in the jurisprudence which exists.

We who believe in the common law think that our system is better than the Continental system. The Continental lawyer, on the other hand, points out with a patronizing condescension that the Roman law existed and functioned long before the naked savages, who were our ancestors, left off staining themselves blue; that theirs is a better and an older culture, and their system a more refined and exact one, and implies that any other is barbarous and fit only for the imperfectly civilized.

For many years sincere attempts have been made to help matters by international convention. We are parties to several, and the effect of them has been good as far as they have gone, or could go, ${ }^{4}$ but, while much was expected of them, they have

4 The Paris Convention of 1883 (revised at Brussels in 1900 and at Washington in 1911) was again revised at the Hague November 6, 1925 . Article 6 Bis. appeared in the revision of 1925 for the first time and contains an implied recognition of rights in trade marks resulting from use and association. It is as follows:

"The contracting countries undertake to refuse or invalidate, cither administratively if their legislation so permits, or at the request of an interested party, the registration of a trade mark which constitutes a reproduction or imitation liable to create confusion with a trade marl: considered by the competent authority of the country of registration to be well known there as being already a mark of a national or another contracting country and used for products of the same or a similar lind.

"A period of at least three years must be granted in order to claim the cancellation of these marks. The period shall start from the date of registration of the mark. No period shall be established to claim the cancellation of fraudulently registered marls."

5 For example, LUCIEN BRUN, TRADE AND Commenchar Manks (Patis, 1897) $\S 321$ says:

"Commerce is essentially international; of all modes of activity of the human intelligence, it is evidently the one which spreads farthest abrosd, and extends to the greatest number of countries. In it, perhaps more than in anything else, honesty is fundamental and indispeneable. It is, then, important that a manufacturer's trade mark, which is, so to spcali, his 
not reached the root of the trouble-the variant views of the manner of acquiring trade mark ownership. No relief seems possible until a serious effort is made to unify, as far as practicable, the domestic legislation of commercial countries. It would be as hopeless to ask a government where the civil law prevails to abandon it and adopt the common law as it would bo for a civil law country to ask us to scrap our system and take theirs. But there seems to be no insuperable obstacle to having the two systems, or necessary modifications of them, go along side by side.

Take, first, the common law as applied to trade marks. A merchant adopts and uses a mark with the result that, by association, his goods become known by it. He seeks to register it in the Patent Office when his business becomes interstate or foreign. The Patent Office makes a search to find out if there is any adverse use or other objection to its registration and, if nothing is found, the mark is published for thirty days to afford an opportunity to anyone, who would be damaged by its registration, to oppose. If no opposition develops, the mark is registered and a certificate is issued which creates a presumption of ownership in the registrant. A certified and legalized copy of this certificate can be filed in foreign countries as the basis of registration there. These proceedings naturally take time, always months, and if there are contests, sometimes years.

signature, and is both the evidence and the assurance of his reputation, since it acquires a real value only through that reputation, and assures the consumer that the goods which he purchases deserve that reputation; it is, I say, important that his mark be fully protected, and to be fully protected, it should be so universally, both as to time and as to space. Uniyersal protection of marks, or, more generally, of industrial proporty, is the present tendency, and we see in this fact one of the greatest forward steps of modern industry and commerce.

"But, to obtain this ideal protection, which must be universal and everywhere equal-that is, uniform in all nations, for that is the ultimate aim-there is but one means, which is, international conventions assuring equality and uniformity of protection throughout the different countries.

"It should here be observed, that a convention, duly published, in so far as it regulates private relations between the subjects of the different states, constitutes a special law. For the points which it covers, a specind law repeals and takes the place of a general law; that is, in this case, the interior laws of each of the contracting countries. A convention is a contract between two States, between two equals, and each of the contracting parties should execute it in good faith. If, then, the law of one of the States is in conflict with the convention, the convention should govern; it alone should be followed and executed, and the contracting country should recast its legislation, so as to bring it into accord with the convention. Tha State is responsible for the faithful execution of its diplomatic trenty.

"Conventions relative to industrial property cannot be too much oncouraged; and this is especially true of international Unions such as thoso of Madrid and Paris, which are the only means of securing that uniformity of legislation and protection which is so necessary in this connection.

"It must not, however, be forgotten that, besides the interest of the producer, however important that may be, there is the interest of the consumer; that is, of the great mass of the public. For this reason great encouragement should be given to the repression of all false marks of origin or quality of goods and of all false names and marks placed upon goods of any kind." 
Now, take a country where the so-called deposit system pievails. An applicant files his trade mark on a printed blank; there is no examination; a certificate issues forthwith and is immediately available for foreign filing. The citizen of a deposit country has thus an enormous advantage, and can beat the trader who lives in a non-deposit country from six months to years in securing foreign protection.

At a meeting of the International Chamber of Commerce, held in Brussels in June, $1925,{ }^{\circ}$ this whole matter was seriously dis-

6 This discussion, at a meeting held in Paris February 12 and 13, 1026, was crystallized into a report and resolution as follows:

"UNIFICATION OF THE LAWS GOVERNING TRADE MIARTS.

"Many efforts have been made to arrive at the unification of lava governing trade marks. An intermational trade marl law committee was created in Germany in 1911, at the suggestion of Dr. Edwin Fatz; the International Conference of Economic Associations which met in Bruezels on April 15-19, 1912; the International Association for the Protection of Industrial Property, all examined this question. MIessrs. Osterrieth, Werthmeier, Kohler, Capitaine have written at length upon the subject. The International Chamber of Commerce also examined this question at the meeting of the Standing Committee on April 24-25, 1925, at which Mresrs. Capitaine and Burrell presented reports which were communicated to members of the Committee.

"M. Osterrieth said that at the root of all the difficulty was the antagonism existing between different systems of laws, that were or were not mandatory. The system of previous examination was in conflict with that of freedom of deposit. Was it practically possible to conciliate the opposing points of view and to arrive at complete unification of laws gorerning trade marks? What method should be adopted? Should a standard law be drafted, or would it be better to begin by talsing up a certain number of questions of detail on which unification might be attainable?

"II. NIaillard insisted on the importance of a difinition of 'tiade marl:; he thought that agreement would only become possible when agreement had been reached on the definition of terms.

"NIr. Burrell thought that this was a fundamental question. He coplainod the operation in Great Britain of the two Registers which were now licpt under the Trade Marks Act. The proposal which he had made in his Miemorandum suggested the institution in all countries of two Registers, 2 Register $A$ in which marks would be registered after preliminary examination, which would give a right of property in the trade marls and real trade mark protection, and $a$ Register $B$ in which marlis would be registered without preliminary examination, with simply a declaratory efrect and merely assuring protection in case of unfair competition.

"In order to minimize the present opposition between the systems of attributive and declaratory registration, Mr. Burrell suggested that countries having a system of preliminary examination should be aslied to introduce in addition a second Register containing marks deposited without preliminary examination. In the same way countries which at present had a mere system of deposit should be asked to introduce a second Register where marks would be registered after examination. There would be no obligation on trade mark applicants to apply for registration after examination and they would be entitled, if they so desired, merely to deposit their marlis, applications for registration after examination being merely facultative. As the consideration of this question could not be undertalien without thorough examination, MIr. Burrell proposed that a special Committee should be appointed for the purpose.

cThe following resolution was unanimously adopted:

"The Committee decides to relegate the question of the unification of the laws of trade marks to a special commission composed of Messrs. Andre, Burrell, MTaillard, Osterrieth and Snijder van Wassenlirlie, together with additional corresponding members, in particular IIr. Rogers of the United States, Mr. Trepla of Poland, MI. Lachout of Czechoslovalia. It invites the special commission to study also questions relating to special liinds of 
cussed by the representatives of the forty countries who were present. A bill prepared by a committee of the American Bar Association seemed to show a way out of the difficulty. ${ }^{7}$ Briefly,

marks, such as defensive marks and provisional trade marks, etc., togother with the question of the duration of protection, etc. The sub-committeo is requested to present its report to the Secretary General of the International Chamber of Commerce before July 1st."

${ }^{7}$ See also English Trade Marks Act (1919) 9 \& 10 Geo. V c. 79; United States Trade Mark Act, 33 Stat. 724 (1905) and amendments collected in U. S. Comp. Stat. (1916) § 9485 et seq; 41 Stat. 533, (1920) U. S. Comp. Stat. (Supp. 1923) § 9516a. "The Vestal Bill," H. R. 6248 now bofore Congress, contains the following provisions:

"Proceedings to Obtain Registration.

"Section 1. That the owner of a Trade Mark in use in commerce within the control of Congress may register such trade mark-

A. By filing in the Patent Office-

(a) A written application addressed to the Commissioner, signed and verified by the applicant, before any officer mentioned in section 15 (b), stating the applicant's name, citizenship, domicile, residence and business address, upon what goods the trade mark is used, the duration of such use, how the right was acquired and, if by succession or assignment, from whom, and upon information and belief that the applicant is entitled to the exclusive use of the trade mark in the United States, and that the applicant is using it in commerce. A description of the trade mark may be included if desired by the applicant or required by the commissioner;

(b) A drawing of the trade mark;

(c) Such number of specimens or facsimiles of the trade mark as actually used as may be required by the commissioner;

B. By paying into the Patent Office the sum of \$10; and

C. By complying with such rules or regulations not inconsistent with laws as may be prescribed by the commissioner.

"Section 2. No mark by which the goods to which it is applied by tho applicant may be distinguished as to source or origin shall be refused registration as a trade mark on account of its nature unless it-

(a) Consists of or comprises immoral or scandalous matter.

(b) Consists of or comprises the flag or coat of arms or other insignia of the United States, or of any State or municipality, or of any foreign nation, or any simulation thereof.

(c) Consists of or comprises the portrait or signature of a living individual unless by his written consent, or the portrait or signature of any deceased President of the United States during the life of his widow, if any, unless by her written consent.

(d) Consists of or comprises a mark which so resembles a trade mark previously used by another as to be likely, when applied to the goods of the applicant, to cause confusion or mistake or to deceive purchasers as to their source or origin.

When such previously used trade mark is applied to merchandise of the same descriptive properties it shall constitute prima facie grounds for refusing registration.

(e) Consists of a mark which when applied to the goods of tho applicant has merely a descriptive or geographical meaning or is merely a surname.

Rejection on any of the foregoing grounds shall be subject to rebuttal by evidence of relevant facts.

(f) Except as expressly excluded in paragraphs (a), (b), (c) and (d) of this section, nothing herein shall prevent the registration of any mark used as a trade mark by the applicant in commerce, which, in accordance with the principles of common law, has acquired a secondary meaning distinguishing the applicant's goods. Substantially exclusive use as a trado mark for five years preceding application shall be prima facie evidenco of secondary meaning.

(g) Registrations of a mark except under paragraph (f) of this section shall be prima facie evidence of ownership as of the date the application was filed. Registration of a mark by virtue of paragraph ( $f$ ) shall be prima facie evidence of the right as of the date the application was filed to prevent others from using the mark in a manner likely to cause con- 
it is proposed to have two trade mark registers, one (which may be called the "A" register) where marlis may be entered after the examination usual in countries where the examination system prevails, and a certificate issued carrying a presumption of ownerships in the registrant; and, in addition, to provide an-

fusion or mistake or to deceive purchasers as to the source or origin of the goods.

"Section 3. In addition to the registration provided in sections 1 and 2 of this Act, the commissioner shall keep a register of-

(a) All marks communicated to him by the international bureaus provided for by the convention for the protection of trade marlis and commercial names, made and signed in the city of Buenos Aires, in the Argentine Republic, August 20, 1910, in connection with which the fee of 800 gold for the international registration established by article 2 of that convention has been paid, which communication and register shall show $a$ faesimile of the mark; the name and residence of the registrant; the number, date and place of the first registration of the mark in the country in which the owner has his main place of business or where he manufactures the product on which the mark is used, including the date on which application for such registration was filed and the term of such registration; a list of goods to which the mark is applied as shown by such registration and such other data as may be required by the commissioner concerning the mark:

Owners of marks so registered, being domiciled in any country which is a party to said convention, shall enjoy, while the registration remains in force, all the rights and benefits conferred by said convention.

(b) In addition to the registrations hereinbefore provided for, the Commissioner shall keep a register of marlis as a continuation of the register of marks heretofore registered under paragraph (b) of Section 1 of the Act of MIarch 19, 1920, entitled ' In Áct to give effect to certain provisions of the Convention for the Protection of Trade Marks and Commercial Names, made and signed in the city of Buenos Aires, in the Argentine Republic, August 20, 1910, and for other purposes.' Whenever any person engaged in manufacturing in, or exporting from, the United States, shall apply for registration of any mark (including therein a trade marl, symbol, label, package, configuration of goods, name, word, or phrase) other than those expressly excluded by paragraphs (a), (b), (c) and (d) of Section 2, used upon goods manufactured by or for such applicant and exported, or about to be exported, to any foreign country, accompanied by a verified showing that no other person has any superior right to the use of such mark for like goods, and shall pay into the Patent Office the sum of ten dollars, the Commissioner, subject to examination and search to determine whether the mark is excluded by paragraphs (a), (b), (c) and (d) of section 2, shall forthwith register said mark in said register and issue a certificate of registration for such mark, which shall ba cvidence of the date of filing the application therefor, and the claim of the registrant of right in such mark. Registration under this section, including marks heretofore registered under paragraph (b) of Section 1 of said $A \mathrm{et}$ of MIarch 19,1920, shall give the registrant the same protestion in commerce of the marks so registered as the common law afiords. Applications under this section shall not be published for opposition as provided in Section 7, and shall not be subject to opposition as provided in Section 13, but the registrations shall be subject to cancellation under section 13 , paragraph (b), or Section 14, paragraph (g). Such registrations shali not be used to stop importations under Section 29."

s It would be conducive to the security of trade mark rights, if marlis which have been upon the register for a certain time should be incontestable. There is such a provision in the British Trade Mrarlis Act of 1005, where a mark registered for seven years is to be talien as valid in all respects. 5 Edw. VII, c. $15, \$ 41$.

I have long entertained the view that, when limited to the commerce over which Congress has jurisdiction and in the regulation of which its power is complete, such a provision in a national act in this country would be constitutional. There has apparently been created, under the treaty malsing power, a class of trade marks the right to which is not dependent upon use, and why, as an instrumentality in the regulation of interstate and 
other, or " $\mathrm{B}$ " register, where marks may be registered without delay, the certificate carrying no presumption (without prejudice, of course, at any time, to a transfer from the " $\mathrm{B}$ " to the " $\mathrm{A}$ " register, after complying with its terms) marks upon the "B" register, in common law countries, to be entitled to the protection which the common law affords and generally against unfair competition, which is a wrong recognized in substantially all civilized nations. If this plan could be generally adopted, many of the present difficulties would be overcome, and its adoption involves nothing radical.

No country is asked to abandon the system which it now has, but merely to supplement it. The countries which register after an examination will continue to do so merely adding a deposit provision to be used by those who need or prefer it and vice versa. Those who wish to retain the established system still will have it, and those who like the other better may use it. No one will be inconvenienced. Each can have exactly what he prefers to use or not as he chooses, or as the circumstances warrant. Quick, simple and inexpensive registration in the " $\mathrm{B}$ " register will be of great benefit to American exporters in permitting them, in foreign countries, to forestall possible piracy and by placing them on an equality with citizens of countries where the deposit system prevails. The " $\mathrm{A}$ " register will benefit citizens of those countries who now complain that their trade marks are not respected because the deposit system and attributive registration are in ill repute.

Of course any discussion of the international situation must assume that owners of trade marks know, or will take pains to find out, what their own, as well as foreign, laws are, and have enough intelligent self-interest to avail themselves of the protection they afford. Otherwise it is time wasted to attempt any improvement.

foreign commerce, Congress should be unable to create a legal presumption of trade mark ownership, incapable of rebuttal. I am unable to perceive. It is only fair, however, to say that the majority of my professional colleagues utterly disagree with me in this. 